\title{
Et jernbaneprojekt fra 1844
}

\author{
(Åbenrå - Haderslev - Årøsund)
}

Af $N . H$. Jacobsen.

I året 1830 åbnedes jernbanen fra Manchester til Birmingham, en begivenhed, der betragtes som indledningen til den revolution i samfxrdselsforholdene, som jernbanerne kom til at betyde. Ganske vist var der $\mathrm{i}$ årene før 1830 blevet anlagt enkelte mindre jernbaner $i$ U.S.A. og i England, hvor den første lille jernbane åbnedes i 1825 mellem Stockton og Darlington, men åbningen af den langt mere betydelige jernbane fra Manchester til Birmingham regnes dog som den første betydeligere jernbane $i$ verden - som "Jernbanealderen «s begyndelse. Få år efter i 1835 åbnedes den første jernbane i Tyskland, nemlig banen fra Nürnberg til den $6 \mathrm{~km}$ nordvest herfor liggende by Fürth, og hermed var så begyndelsen lagt til den jernbanefeber, som med voldsom hastighed bredte sig over Tyskland og det øvrige Europa i de følgende år.

Men medens $f$. eks. den franske og den belgiske regering fulgte det princip at lade jernbanerne bygge af staten, så var denne vigtige sag i Tyskland overladt til det private initiativ. Resultatet var, at der i de følgende år fremkom en mængde mere eller mindre gennemtænkte og ofte ret usandsynlige planer om jernbaneanlæg. I Hamborg opstod der en fuldstæendig mani for at få fat $\mathrm{i}$ jernbaneaktier, og også på Europas børser var der en voldsom efterspørgsel efter aktier i de påtænkte tyske jernbaner.

Et meget grelt udtryk for denne jernbanefeber findes $\mathrm{i}$ "Dannevirke" for den 24 . april 1844, hvor der bringes følgende meddelelse: »Redaktøren af et Rendsborg-ugeblad, hr. rektor Lütgens, synes desværre at være blevet rent besat af den på halvøen indtrængte jernbane-nisse «. Og bladet fortsætter med at citere en overmåde malende udtalelse, hvori vedkommende Lütgens skriver: "Vi har allerede smagt jernbanesiruppen, og om det gjaldt liv eller død, så 
projekterer og spiller vi dog hasard med aktier, og gik verden til grunde, så begynder vi dog $\mathrm{i}$ himlen påny «.

Det er ganske naturligt, at man på et meget tidligt tidspunkt fik øjnene op for den betydning, som jernbanerne i Slesvig og Holsten ville kunne få. Den korte afstand, der her er mellem Nordsøen og Østersøen, har igennem århundrederne været med til at præge samfærdselsforholdene $\mathrm{i}$ disse egne og har $\mathrm{i}$ tidens løb bl. a. fremkaldt adskillige planer, der gik ud på, at der etableredes en kanalforbindelse mellem de to have. ${ }^{1} \mathrm{Og}$ når den danske regering på et så tidligt tidspunkt som i midten af 1830'rne kom til at beskæftige sig med planerne om jernbaneanlæg $i$ hertugdømmerne, skyldtes det de preussiske projekter, som skulle fremme transithandelen mellem Hamborg og Lybæk, en trafik, der delvis skyldtes, at man ad denne vej kunne omgå øresundstolden, og som naturligvis ville blive yderlig fremmet ved anlæg af en jernbane.

Den danske regering havde den opfattelse, at den eneste måde, på hvilken de preussiske planer kunne forhindres, var anlæg af en transitbane på det danske monarkis territorium, og for nærmere at tage stilling til, hvor en sådan bane skulle anlægges, nedsattes den 10. december 1835 Den kongelige Jernbanekommission. Denne kommission skulle, som det fremgår af jernbanebekendtgørelsen af 18. maj 1840, behandle vilkårene for anlæg af transitbaner i Slesvig og Holsten. Bekendtgørelsen bestemte, på hvilke betingelser enkeltpersoner eller private selskaber kunne forvente at få tilladelse til anlæg af jernbaner "til forbindelse af Nordsøen og Østersøen gennem hertugdømmet Slesvig eller hertugdømmet Holsten «. Muligheden for andre linjeføringer blev overhovedet ikke nævnt. Betingelserne var bl. a., at der ikke måtte dannes jernbaneaktieselskaber, medmindre de havde fået koncession af staten.

Det første resultat af jernbanekommissionens arbejde var "Christian VIII's Nordøstersøjernbane" fra Altona til Kiel. Denne bane åbnedes på Christian VIII's fødselsdag den 18. september 1844. De synspunkter, der lå til grund for bygningen af Altona-Kiel jernbanen, var anerkendelse af den betydning, som jernbaner ville kunne få for det danske monarkis handel med udlandet. »For baner $\mathrm{i}$ selve kongeriget nærede man derimod fra statens side absolut ingen interesse $\alpha^{2}$

Men fra mange sider begyndte man imidlertid at sysle med tanken 
om anlæg af jernbaner. Denne interesse voksede sig dog ikke stærk lidt efter lidt, men den brød faktisk pludselig og uventet frem i foråret 1844, da den gav sig udslag $i$ fremkomsten af en mængde mulige og umulige projekter. Staten gav rundhåndet koncession til nivelleringen af de påtænkte banestrækninger, og overalt troede man, at med en sådan koncession var så også tilladelsen til at kunne foretage aktietegning til den pågældende jernbane givet. Ethvert projekt blev bestormet af folk, der ønskede at tegne aktier, indtil — som det skete i de fleste tilfælde - reaktionen kom, og projektet fortabte sig $\mathrm{i}$ morket.

Der var god grund til, at disse hastigt opdukkende aktieselskaber, som for en stor del var rene svindelforetagender, kom under et vist tilsyn fra statens side, og under 14. juni 1844 blev opgaven for den i 1835 nedsatte kongelige jernbanekommission udvidet til ikke blot at tage sig af jernbaner i Slesvig og Holsten mellem Nordsøen og Østersøen, men til for fremtiden at behandle alle de jernbaneplaner, der kom frem i hele monarkiet. ${ }^{4}$

Det stærke røre omkring anlæg af jembaner betød dog ikke, at der var absolut enighed om onskeligheden af at få dette nye trafikmiddel, ligesom der herskede stærkt divergerende meninger om, hvorledes hovedtrækkene $\mathrm{i}$ det fremtidige jernbanenets linjeføring skulle være.

Her skal ganske kort anføres nogle enkelte af de synspunkter, der blev fremført. I en indberetning af 1841 til rentekammeret om jernbanernes betydning opkaster Gustav Skram, der i 1840 til Industriforeningen havde indsendt et forslag om dannelsen af et aktieselskab for at anlægge en jernbane fra København til Roskilde, det spørgsmål, om Danmark på grund af sin geografiske beliggenhed i det hele taget havde brug for en jernbane. Dette mente han absolut var tilfældet. Man kommer her uvilkårligt til at tænke på, hvad den kendte landøkonom C. F. I. Dalgas havde skrevet kun 14 år tidligere om, at $\gg i$ et land som Jylland, der ved sine udstrakte kyster har lejlighed nok til sejlads, og hvor varetransporten altså ikke kan være betydelig, er vore aimindelige landeveje, når de på den nu brugelige måde vedligeholdes og forbedres, mere end tilstrækkelige til posternes og de fă rejsendes transport «. $^{\mathrm{b}}$

Efter Skrams mening var jernbanerne i Danmark en bydende nødvendighed, hvis ikke landet skulle gå sin totale undergang i møde." 
Lignende, noget højstemte toner var der over det, som sekretær Hjort udtalte ved Industriforeningens generalforsamling den 23. maj 1844: »At dette nye kommunikationsmiddel, der med rette betragtes som de nyere kunsters triumf, måske vil blive det kraftigste middel til at forebygge krig og modvirke den separatistiske ånd, som på flere steder, ja, desværre også her $i$ landet $i$ den senere tid har udviklet sig, ja, i det hele taget, at befordre det åndelige og materielle livs udvikling på en sådan måde, som man må se for at kunne gøre sig forestilling derom $\kappa^{7}$

Og noget lignende lød på samme tid fra Sønderjylland. Den 15. maj 1844 hedder det $\mathrm{i} »$ Dannevirke : $»$ Det er at indse, at det hos os voldsomt opståede jernbanevæsen ikke vil kunne ordne sig uden adskillige lokalkampe. I hvert tilfxlde synes jernbanernes imponerende indflydelse at ville fortrænge alle vore sproglige og nationale fejder og ligesom ved en mægtig jernhånd sammenknytte de hvert år sig mere løsnende bånd mellem statens dele og gøre enhver søndersplittelse for evig umulig «.

Imidlertid var der som nævnt blandt dem, der gik ind for anlæg af jernbaner, meget delte meninger om, efter hvilke synspunkter det kommende jernbanenet skulle anlægges. Skulle der for Jyllands vedkommende foretrækkes en bane, der strakte sig op gennem halvøen $i$ retningen nord-syd, eller skulle man vælge en øst-vest gående tværbane.

Uenigheden fremgår tydeligt af besvarelserne af spørgsmålene $i$ det spørgeskema, som Den kongelige Jernbanekommission i midten af $1840^{\prime}$ rne udsendte til samtlige amtsråd og byråd i Jylland.

Stort set var det således, at amtsrådene, der først og fremmest representerede de store landbrugere, mente, at jernbanen ville blive til overmåde stor gavn for landbruget - i særlig grad da for studeopdrætningen og studehandelen, idet det herefter ville kunne betale sig at fede studene op i Jylland $i$ stedet for at sende dem til markederne mod syd i den magre tilstand, som de måtte være $i$ efter det overordentlig store vægttab, som de måtte lide ved at skulle drives fra Nordjylland til markedet mod syd. Desuden ville en jernbane op gennem Midtjylland kunne få stor betydning for de magre jorders opdyrkning.

Også indenfor købstæderne var der mange, der mente, at en jernbane ville blive til gavn for landbruget, men ellers var byrådene med 
temmelig få undtagelser enige om, at en langdebane ville være til skade for byerne. Man mente blandt andet, at ved anlæg af en længdebane ville købstædernes handel og håndværk blive udkonkurreret af Hamborg, og at skibsfarten på de jyske havne ville aftage.

Og endelig kom hertil, at jernbaneanlæggene fra at være et okonomisk stridsspørgsmål mellem land og by nu også meget tidligt blev et politisk og nationalt spørgsmål mellem nationalliberale på den ene side og helstatsmænd på den anden side. Typisk er således udviklingen af roskildebanens historie. Denne bane var oprindelig tænkt som et led $\mathrm{i}$ en nærmere forbindelse med Hamborg, men blev for de nationalliberale basis for et jernbanesystem, hvis hovedformål var at samle landet $i$ en økonomisk enhed med København som midtpunkt, isolere os sydpå og i stedet for lette forbindelsen til England. ${ }^{\mathrm{s}}$

Således var forholdene, da man i foråret 1844 udkastede planerne om en jernbane, der fra Ảbenrå skulle gå over Haderslev til Årøsund. Grunden til denne plans opstån var, at komiteen for en jernbane fra Rendsborg til Flensborg i 1844 havde fået kongelig tilladelse til at lade den pågældende strækning nivellere. Den nødvendige aktiekapital var sikret, og der syntes således efter komiteens opfattelse at være lyse udsigter.

Samtidig fremsattes også et projekt om en jernbane fra Flensborg over Husum til Tønning. Det var $\mathrm{i}$ øvrigt ret forbavsende, at en stor del af aktierne til denne bane blev tegnet af hamborgere, selvom banen ville være i direkte modstrid med Hamborgs interesser.'

Forventningerne om, at der ville komme en jernbane fra Rendsborg til Flensborg, bevirkede, at man nu også begyndte at interessere sig for en fortsættelse af en sådan bane mod nord. I Åbenrå blev der nedsat en komité bestående af borgmester Schow, agent Jørgen Bruhn og de deputerede Lüders og Karberg, som skulle arbejde på at gennemføre en forlængelse af den forventede Rendsborg-Flensborg jernbane til Ảbenrå. ${ }^{10}$

I Haderslev så man med megen misbilligelse på, at en deputation fra Ābenrå var rejst til Slesvig for at rådføre sig med de mænd, der var interesseret $i$ at $f_{a}^{\circ}$ en bane fra Flensborg til Ábenrå, "hvortil pengene ventelig ligger parat i Hamborg «, som "Dannevirke« skriver $i$ en artikel med overskriften: "Virvar - Den $i$ hertugdømmerne opståede jernbane-hurlumhej vedbliver at stige«. Og bladet fortsætter: "Som man hører, er det også de gode åbenråeres idé, at deres 
by skal være endepunktet af den hele bane, thi det er endepunkterne, hvortil alt søger og alt igen udgår, der har den store profit. Dette er rigtignok et forræderi mod broderbyen Haderslev og en svigten af den kærlighed, som $\mathrm{i}$ fjor forenede haderslevere og åbenråere $\mathrm{i}$ Hundeklemmen, men enhver er sig selv nærmest "."

Det møde, der hentydes til, og som blev afholdt den 12. juli 1843 på et af de smukkeste steder vest for Åbenrå, var arrangeret af slesvig-holstenske kredse som en modvægt til det den 18. maj samme år afholdte møde på Skamlingsbanken.

Den 24. april 1844 kunne "Dannevirke" yderligere meddele, at »i følge pålidelige efterretninger har magistrat og deputeretkollegium [i Ảbenrå] afsluttet en kontrakt med hr. Jacob Meyer fra Rendsborg, allevegne kendt for sine store markeds-plakater og "uhørt « billige priser, om at skaffe byen en jernbane til Flensborg. En sikker kaution, at banen ikke skal blive forlænget til Haderslev, har han desværre ikke kunnet bringe tilveje «.

Ved kongelig resolution af 24 . maj 1844 meddeltes der komiteen i Ảbenrå tilladelse til nivellering af en jernbane fra Flensborg til Ảbenrå. Videre kom planen imidlertid ikke, og i stedet for søgte man nu af al magt at fremme chaussébygningen mellem de to byer. ${ }^{12}$

En anden plan, der heller ikke blev til noget, gik ud på, at der skulle bygges en jernbane fra Flensborg til Sønderborg med fortsættelse til Mommark eller Fynshav, hvorfra der så skulle være forbindelse med dampskib til Fåborg. ${ }^{18}$

Men jernbanesagens fremtrængen mod nord var ikke standset med den uheldige skxbne, der var overgået Åbenrå-projektet.

Onsdag den 24. april 1844 kunne "Dannevirke" meddele, at "sidste fredag indtraf hos hr. gxstgiver og agent Petersen tvende herrer fra Rendsborg, som ville underhandle om en jernbanes anlaggelse fra Ảbenrå til Haderslev. Om eftermiddagen holdt en del venner af sagen møde hos hr. agent Petersen, som åbnedes af kammerjunker og amtsforvalter von Krogh fra Āstrup. Publikum svæver endnu $\mathrm{i}$ uvished om, hvad der blev forhandlet på dette møde, men så meget synes at være sikkert, at det ikke er kommet til noget bestemt resultat, fordi de rendsborger herrer ikke kunne forevise papirer fra solide handelshuse. "Lyna synes dog at være nøje underrettet om denne sag, thi den beretter, at Haderslevs indvånere har håb om at få en jernbane fra Ảbenrå over Haderslev — formentlig 
i følge bestemmelse, der er taget i det omtalte møde - til Årøsund «.

Det var altså det slesvig-holstenske blad »Lyna «, der var bedst orienteret om den nu fremkomne jernbaneplan, og i den følgende tid beklager "Dannevirke sig gentagne gange over, at der ikke er kommet noget offentligt frem om denne sag. Den 1 . maj meddeler "Dannevirke « således, at "de rendsborger herrer, som for en 10 dage siden ved deres nærværelse bragte sagen $i$ live, var atter her $i$ søndags. Hvad de igen har forhandlet med de herrer, som på byens vegne har påtaget sig at realisere dette anliggende, er, som antydet, endnu ubekendt. Der hersker imidlertid blandt borgerne spæendthed og uro. Under dette bevarer "Lyna « endnu sin tavshed “. Den 11. maj skriver "Dannevirke«: "Det slør, som hviler over jernbanesagen $\mathrm{i}$ Haderslev, er endnu ikke løftet. Hvorlænge »Lyna «en vil lade byens borgere og indvånere forblive $\mathrm{i}$ uvished om forhandlingerne om denne så vigtige sag, må vi lade være usagt «.

Det var således tilsyneladende de slesvig-holstenske kredse i Haderslev, der især gjorde sig anstrengelser for at få en jernbane, som fra Åbenrå skulle gå til Haderslev og derfra videre til Årøsund, og et af hovedmotiverne for ønsket om at få denne jernbane fremgår af det andragende, som den slesvig-holstenske forening i Haderslev det følgende år - 30. oktober 1845 - indgav til kongen, og hvori det blandt andet hedder: »Med glæde hilste vi også den dag i foråret 1844, da der i Haderslev sammentrådte en komité af patriotisk sindede mænd for at fremme et jernbaneanlæg fra Årøsund over Haderslev til Apenrade, der fortsat over Flensborg, Slesvig og Rendsborg skulle tilvejebringe en direkte forbindelse imellem Lille Bxlt og Hamborg «. ${ }^{14}$

Der nedsattes nu en komité "til sikring af den påtænkte - i tilslutning til Flensborg-Åbenrå-jernbanen - jernbane fra Åbenrå til Haderslev og derfra videre til Årøsund, hvilken bane vil sætte de projekterede danske jernbaner på Sjxlland og Fyn i forbindelse med baner $\mathrm{i}$ hertugdømmerne Slesvig og Holsten “. Komiteens første indsats var en skrivelse af 16 . maj 1844, hvori komiteen udsteder fuldmagt til handelshuset Lawaetz \& Koch i Altona til at lade foretage tegning af 7000 aktier à 100 specier. Hertil kom så 500 aktier à 100 specier, som skulle reserveres til tegning i Slesvig. Fuldmagten slutter med at fastslå, at aktionærerne kun er bundet af tegning, "såfremt den landsherrelige koncession er opnået inden seks måneder fra 1 . juni at regne ${ }^{15}$ 
Fuldmagten er underskrevet af hele komiteen, der bestod af følgende: Kammerjunker og amtsforvalter von Krogh, agent J. C. Petersen, rådmand C. A. Petersen, ejeren af Årøsund, agent C. H. Bruun, advokat Selig, købmand N. C. K. Hansen, købmand H. de Wolff, herredsfoged Thomsen, købmand P. Giørtz og aktuar, dr. Meyer.

Det gik meget hurtigt med at fa aktierne tegnet. Allerede den 18. maj kunne Lawaetz \& Koch meddele, at tegningen af de 7000 aktier var afsluttet. Af den fortegnelse over aktietegnerne, som fulgte med skrivelsen, fremgår det, at den overvejende del af dem var jødiske forretningsfolk. Men tilsyneladende var ikke alle, der havde tegnet sig for aktier i dette jernbaneanlæg fra Ảbenrå over Haderslev til Årøsund, helt klar over, hvad det drejede sig om. I følge »Lyna " for den 29. maj 1844 havde "Altonaer Mercur " bragt en meddelelse om, at »mange på børsen i Hamborg havde forvekslet det sidste navn med $\varnothing$ resund og ikke kunne begribe, hvorledes man fra Haderslev sans façon kunne projektere en så lang bane på én gang «.

Der begyndte nu at komme gang $\mathrm{i}$ jernbanesagen. Den 29. maj indsendtes til kongen en af hele komiteen underskrevet ansøgning om tilladelse til at lade den pågxldende jernbanelinje nivellere på egen bekostning, og den 2. juni rejste en deputation fra komiteen til København for yderligere at lægge et godt ord ind for ansøgningen. Deputationen bestod af kammerjunker von Krogh og rådmand C. A. Petersen samt agent Bruun fra Årøsund. Allerede den 15. juni forelå den kongelige resolution, der gav den ønskede tilladelse.

Men det var ikke blot i Haderslev, at en komité arbejdede på at få tilladelse til at anlægge en jernbane. Den 8. juni 1844 bragte "Lyna « en meddelelse om, at en deputation fra Kolding og Middelfart den 29. maj var afrejst til København for wat andrage Hans Majestæt kongen om allernådigst tilladelse til et jernbaneanlæg fra Haderslev over Kolding og Middelfart til Odense«. Denne deputation vendte tilbage med et lofte om, at sagen skulle blive nærmere overvejet.

Også på Fyn arbejdede man i øvrigt nu med jernbaneplaner. Da meddelelsen om, at aktietegningen til Ảbenrå-Haderslev-Årøsund jernbanen var afsluttet, forelå, fremsattes planerne om en fynsk jernbane, der fra Nyborg skulle gå over Odense til Assens, og som skulle slutte sig til den i Ãrøsund endende linje. Kommunalbestyrelserne i 
de tre byer havde på flere møder drøftet dette anlæg, »der synes at finde megen sympati såvel $i$ ind- som udlandet, og som formodes at ville blive et vigtigt led i den store jernbanekæde, hvormed man agter at sammenknytte Skandinavien og Tyskland ". ${ }^{16}$

Imidlertid var Haderslev-komiteen kommet ud for de første vanskeligheder. Årsagen hertil var den bekendtgørelse, som Den kongelige Jernbanekommission havde set sig nødsaget til at udstede den 19. juni 1844. Bekendtgørelsen påpeger, hvorledes der »i den sildigere tid uden foregående allerhøjeste tilladelse er blevet udstedt indbydelser til aktietegning på jernbaneanlæg «, og at de i denne forbindelse udstedte dokumenter er blevet genstand for en - "for den private kredit" - skadelig spekulation. I den anledning "bliver i folge Hans Majestæt kongens allerhøjeste befaling bragt til offentlig kundskab «, at indbydelse til aktietegning på jernbaneanlæg uden forud erhvervet allerhøjeste tilladelse til aktietegning er blottet for al hjemmel. Ligeledes minder kommissionen om, at det alene er "jernbaner, som har forbindelsen af Nordsøen og Østersøen til formål «, som kan forvente begunstigelser. Begunstigelser for andre jernbaneanlæg »kan følgelig kun forventes $i$ det tilfælde, da et sådant foretagendes fremme af almindelige statshensyn findes tilrådeligt, hvorom $\mathrm{i}$ ethvert tilfælde særdeles allerhøjeste bestemmelser vil blive afgivet ${ }^{17}{ }^{17}$

Denne bekendtgørelse skabte en hel del usikkerhed blandt mange af dem, der havde tegnet aktier i Åbenrå-Haderslev-Årøsund jernbanen, og det skulle senere vise sig, at de havde grund til at nære disse bekymringer. I en meget skarp skrivelse, der er dateret $\$ \mathrm{Ham}-$ burg im Juni 1844«, og som er underskrevet af 26 mænd, der ialt havde tegnet sig for 3925 af de 7000 aktier, hedder det som indledning: $\gg \mathrm{Da}$ undertegnede tiltrådte forpligtelsesskrivelsen, som var bragt i omløb af den provisoriske komité for den projekterede ẢbenråHaderslev-Årøsund jernbane, gik de ud fra den selvfølgelige forudsxtning, at den provisoriske komité bevægede sig på lovens grund og i særdeleshed havde overholdt og fremover var besluttet på samvittighedsfuldt at iagttage de anvisninger, som den kongelige danske lov af 18. maj 1840 foreskriver «.

Derefter anføres, hvorledes de underskrevne mener, at komiteen helt har ignoreret de normer, der er foreskrevet $i$ bekendtgørelsen af 19. juni 1844, »og at hine forehavender $\mathrm{i}$ følge denne publikations udsagn savner ethvert lovligt grundlag«. 
Underskriverne tager alle mulige forbehold overfor eventuelt forekommende uregelmæssigheder og slutter: »Når derimod den provisoriske komité for Åbenrå-Haderslev-Årøsund jernbanen har holdt sig nøje indenfor de lovlige grænser, så vil den under de givne omstændigheder finde det meget forklarligt, at undertegnede tillader sig at minde om, som det er selvfølgeligt, og som det jo også er foreskrevet ved udtrykkelige lovbestemmelser, at der fremover ikke må foretages skridt af nogensomhelst art i dette anliggende, før der har været afholdt en generalforsamling for samtlige aktionærer, til hvilken disse indkaldes rettidigt, så de kan give møde enten personligt eller ved befuldmægtigede stedfortrædere«.

Men imens fortsætter komiteen arbejdet med jernbaneplanerne, og den 8. oktober 1844 indgav den så ansøgning til Den kongelige Jernbanekommission om tildeling af koncession på bygning af den projekterede jernbane, samt om foreskrivelse af en frist for modtagelsen af tegninger til de 500 resterende aktier.

Dette meget udførlige aktstykke giver en indgående redegørelse for ønsket om at få denne bane anlagt, og det er da også væsentlig på dette dokument, at det følgende er baseret.

Efter at man ved kongelig resolution af 15 . juni havde fået tilladelsen til at foretage nivellering af banestrxkningen, blev dette arbejde på anbefaling af overingeniør Dietz overdraget til ingeniør Trede. Foruden at optage en længde- og tværprofil af banestrækningen, to aktstykker, som det desværre ikke har været muligt at finde frem til, udarbejdede ingeniør Trede et overslag over udgifterne ved dette jernbaneanlæg. Dette overslag, som blev attesteret af overingeniør Dietz, resulterede $i$, at udgifterne ved anlægget af den $51 / 2$ "postmil" (ca. $40 \mathrm{~km}$ ) lange bane ville beløbe sig til 2.760 .000 mark, altså 501.212 mark pr. mil, en sum som ikke overskred det beløb på 2.812.500 mark, som man fik ved tegningen af 7.500 aktier à 100 specier.

Om jernbanens forløb hedder det, at den fra Ảbenrå skulle gå i en svag bue mod øst over en mosestrækning for derefter at bøje mod vest op gennem et dalstrøg til Rise Hjarup. Herfra skulle banelinjen gå over Lerskov og Øster Løgum til Hovslund $\mathrm{i}$ en næsten lige linje og over et terræn med overvejende sandet jordbund. Fra Skovby fik banen en mere østlig retning mod Vartenberg kro, $\mathrm{i}$ hvis nærhed der måtte bygges en bro for at føre banen over det dalstrøg, der findes 


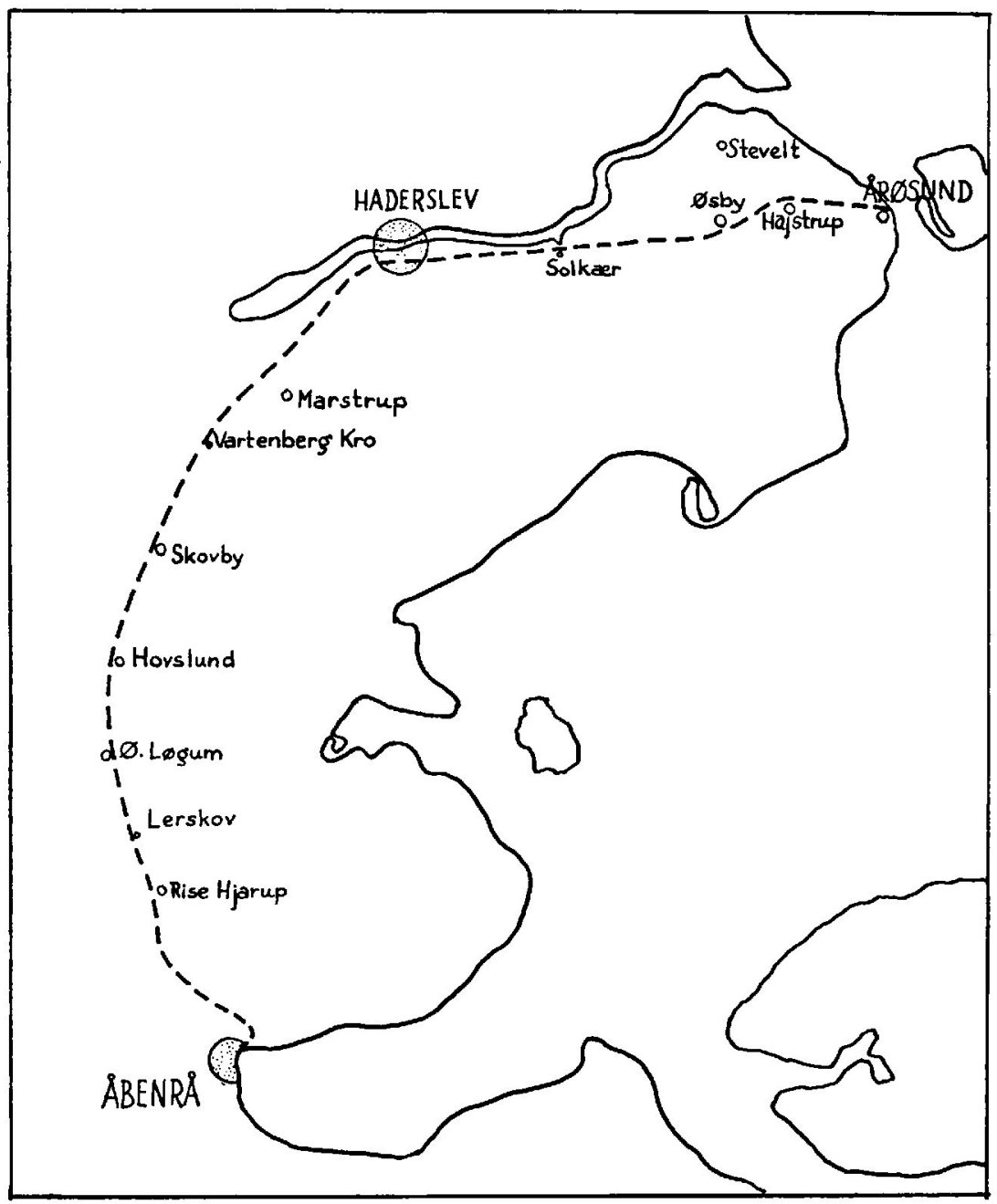

Jernbaneprojektet fra 1844.

her. På den videre strækning over Marstrup til Haderslev dannede banelinjen to svage kurver. Fra Haderslev skulle jernbanen gå langs fjorden til Solkær, hvorfra den passerede syd om gården Sparlund og landsbyen Øsby. Den sidste del af banelinjen var lagt nord om Hajstrup og derfra i sydøstlig retning til Årosund havn.

Niveauforholdene var efter komiteens opfattelse i det store og hele 


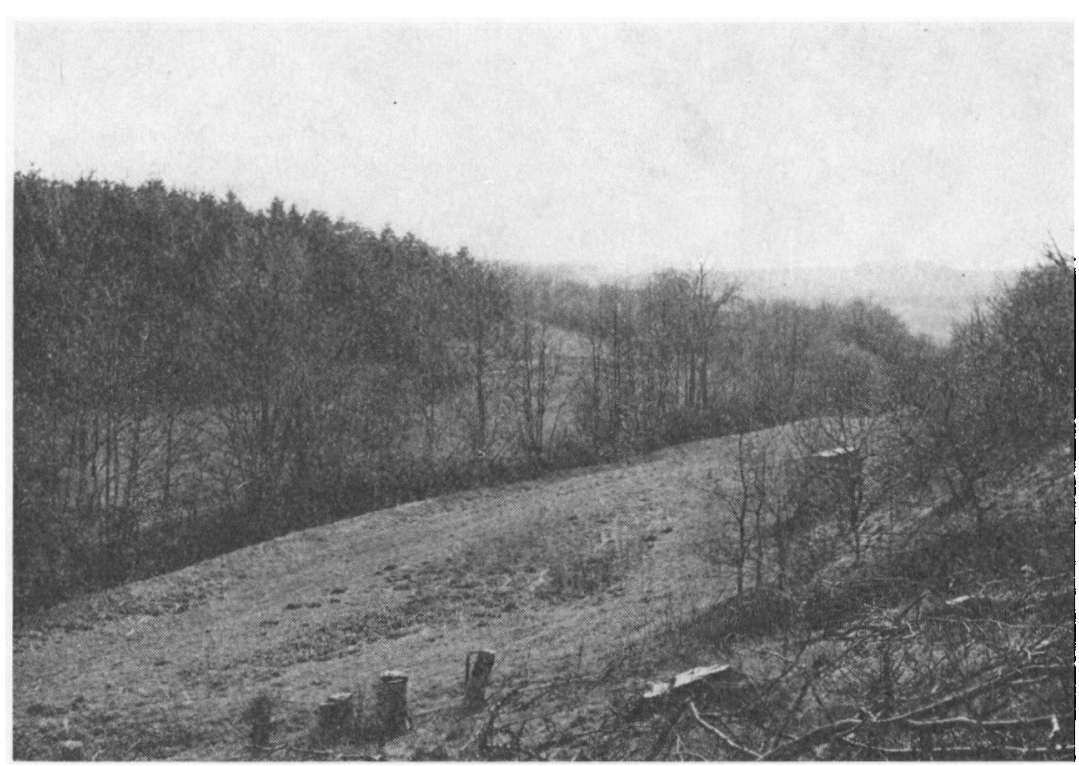

Parti af dalen ved Vartenberg kro. Det sandsynligste sted for broen til den påtcenkte Abenrä-Haderslev-Arosund jernbane.

gunstige, selvom banelinjen flere steder fører gennem et ret vanskeligt terræn. Der er ingen skarpe kurver. Den største stigning - som findes ved Ảbenrå og Haderslev - er på $1 / 100$, medens den på den øvrige del af linjen ligger mellem $1 / 150$ og 1/400. De største gennemskæringer forekommer ved Åbenrå, Rise Hjarup og Vartenberg kro samt ved Sparlund, Øsby og Hajstrup.

Udgifterne til jordarbejderne beregnedes til at skulle blive 980.942 mark eller $351 / 2 \%$ af anlægsudgifterne, medens der til broer $\mathrm{m}$. $\mathrm{v}$. skulle anvendes 63.800 mark. Omkostningerne ved ekspropriationerne blev anslået til 187.000 mark eller $6^{3 / 4} \%$ af anlægsudgifterne - et ret højt beløb $\mathrm{i}$ betragtning af, at banen for størstedelen kom til at gå gennem et ikke særlig frugtbart terræn. Endelig skal anføres, at man til anskaffelse af lokomotiver, vogne og værktøj regnede med at skulle bruge 290.800 mark, medens opførelsen af de tre banegårde ville komme til at koste ialt 308.900 mark.

Komiteen erkender, at den samlede udgift gennemgående er ansat meget højt, men mener, at det uden tvivl vil være en gunstig omstæn- 
dighed for den projekterede jernbane, at de anslåede udgifter ikke overskrider det beløb, som aktietegningen udviser.

Derefter melder så det spørgsmål sig, om de egne, som banen skal gå igennem, frembyder sådanne forhold, at jernbanen vil kunne blive et frugtbringende foretagende, men komiteen tror - med henvisning til det vedlagte prospekt over banens rentabilitet, som senere vil blive lidt nærmere omtalt - at kunne fastslä, at den ønskede jernbane ikke alene vil være af stor betydning for Haderslev, men at den $i$ det hele taget vil kunne forrente sig godt.

For Haderslev vil anlægget af denne jernbane efter komiteens mening blive en kilde til velstand, idet den for det forste vil bevirke en opblomstring af den industri, som der $i$ de senere år har vist sig så stor interesse for, samt fordi Haderslev vil blive et vigtigt led $\mathrm{i}$ trafikken fra de sydlige egne, fra det vestlige Slesvig og fra Jylland, som ad denne nye bane vil blive ført videre over det gamle overfartssted Årøsund.

Det er da ganske forståeligt, at bykollegiet i Haderslev var interesseret $i$ den projekterede jernbane, og $i$ en skrivelse af 1 . juni 1844 til jernbanekomiteen erklærer bykollegiet da også, at det overfor kongen vil anbefale anlæggelsen af jernbanen, men kollegiet vil dog kun gøre det under den forudsætning, at banegården i Haderslev skal anlægges på byens grund, og at kollegiet får lejlighed til at varetage byens interesser ved bestemmelsen om banegårdens placering.

Banens betydning skulle dog ikke, som nævnt, ses alene udfra rent lokale forhold, men også - og i nok så høj grad - udfra den betydning, den ville kunne få for den gennemgående trafik, og der blev da også, som tidligere omtalt, fra begyndelsen fremhæret det ønskelige $\mathrm{i}$ at få en direkte forbindelse fra Hamborg til Lille Bælt.

Når det blev netop Årøsund, som man ønskede at gøre til endestation for en jernbane op gennem Slesvig, skyldtes det den betydning, som dette sted i kraft af sin beliggenhed allerede meget langt tilbage $i$ tiden har haft for forbindelsen mellem Slesvig og Fyn.

Uden at gå $\mathrm{i}$ enkeltheder skal her kun påpeges enkelte af de træk, der viser den betydning, som overfarten Årøsund-Assens har haft gennem tiderne.

Mærkeligt nok figurerer Arøsund-Assens overfarten ikke i Kong Valdemars Jordebog fra 1231. Af sønderjyske færgesteder nævnes her kun Varnæs. Men i Haderslev stadsret fra 1292 fastsættes i 
artikel 7 taksterne for overførsel af passagerer, heste, kvæg, får og svin og sait, idet det fremhæves, at Haderslevs borgere er fritaget for at betale færgeafgiften. ${ }^{18}$

I århundreder hævdede denne overfart over Lille Bælt sin rang, og denne blev naturligvis ikke mindre, da Christian I i 1475 hertil henlagde al udførsel af kvæg fra Fyn. Færgeoverfarten blev stærkt benyttet som den hovedrute, den faktisk var. Foruden til almindelige overfarter blev den ofte anvendt til troppetransporter, ligesom det gentagne gange skete, at kongerne rejste ad denne vej.

Arøsund-Assens overfartens betydning understregedes yderligere, da postruten blev lagt ad denne vej, som derved blev hovedpostforbindelsen for brevpost mellem de danske oer og hertugdømmerne samt Hamborg. Da postkontoret i Haderslev oprettedes i 1649, befordredes den ridende post én gang ugentlig over Årøsund-Assens, ligesom tilfældet var med den svenske postrute til Hamborg, som svenskerne ved freden i Brømsebro havde fået ret til at føre gennem Danmark. Men medens den danske post var nødt til at lægge vejen over det jyske hovedpostkontor i Haderslev, kunne den svenske post skyde genvej over Haderslev Næs, idet den lagde vejen over Vilstrup og Hoptrup. ${ }^{10}$

Fra Frederik III's tid blev Haderslev nemlig et virkeligt knudepunkt $\mathrm{i}$ de danske postruter, idet krydsningspunkter for de jyske postruter blev forlagt fra Kolding til Haderslev, hvorfra der så gik "agende* poster til Ålborg, Viborg samt til Ringkøbing over RibeVarde. ${ }^{20}$ Forbindelsen med Hamborg lettedes betydeligt, da der den 1. april 1834 åbnedes en diligence, der to gange om ugen gik fra Hamborg til Årøsund og derfra videre til København. Allerede to år $\mathrm{i}$ forvejen havde Fyns guvernør, prins Christian Frederik, foreslået anskaffelsen af et dampskib til overfarten Assens-Årøsund. Postvæsenet turde dog ikke anbefale planen, da antallet af rejsende var for lille, men prinsen fortsatte sine bestrxbelser, og resultatet blev, at dampskibet "Maagen «, der havde en maskine på 20 hestekrxfter, og som havde kostet 27.311 rdl., i september 1838 blev indsat på denne overfart - kun 10 år efter, at der var blevet indført dampskibsfart mellem Korsør og Nyborg.

I henhold til kontrakt af 28. april 1837 blev "Maagen « overladt til færgeriejer H. B. Bruun og transportforvalter $\mathrm{H}$. Chr. Bruun det senere medlem af jernbanekomiteen - i Ãrøsund. Disse mænd 


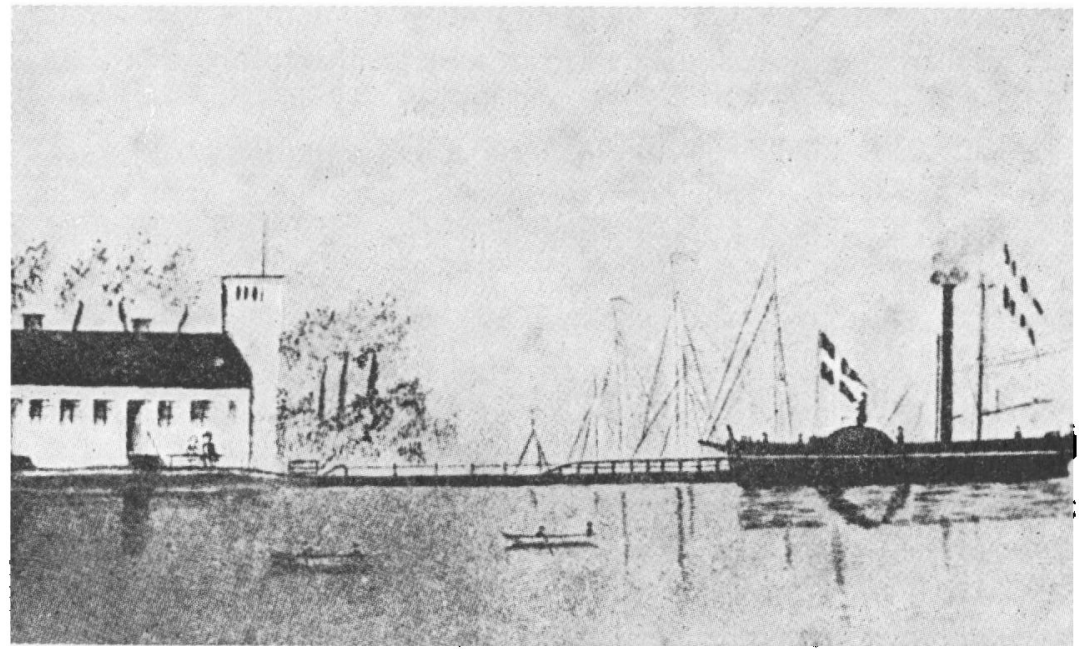

Assens-Arosund overfarten. Dampskibet „Maagen“ sejler ind til Arosund.

(Lauritz Maaloe: Assens gennem 700 år. Odense 1936).

fik dampskibet til disposition i 20 år og skulle for dette tidsrum have 5300 rdl. årligt for postens overførsel..$^{21}$

Samtidig med, at overførselsforholdene fra Årøsund til Assens således var blevet væsentlig forbedrede, indså man det ønskelige $i$, at vejen fra Haderslev til Ãrosund blev sat $i$ bedre stand, og i vejloven af 1. marts 1842 blev denne vej da også opført som en af de veje i Slesvig, der skulle udbygges som hovedvej. Ved »hovedvej« forstod man en vej, der skulle formidle indførsel og udførsel og gennemgående trafik $i$ hele landet.

Men hvorledes var forholdene nu i det hele taget her i Årøsund $\mathrm{i}$ året 1844? Hvilken betydning havde dette sted som havn? Om disse spørgsmål giver ejeren af Årøsund, agent C. H. Bruun, en ret udførlig besked $\mathrm{i}$ en indberetning, der er dateret den 30. juli 1844, og som blev vedlagt en skrivelse af 6. november 1844 fra agenterne J. C. Petersen og C. H. Bruun til Den kongelige Jernbanekommission. I denne indberetning betegnes Årøsund direkte som Haderslevs udhavn, og der tilføjes, at den 2 mil lange Haderslev fjord kun er tilgængelig for småskibe med 5-6 fods dybtgående. Den er et besværligt farvand. Ikke alene bugter den smalle sejlrende sig gennem skovbevoksede kløfter, hvor vindforholdene tilmed er meget ustadige og 
varierende, men desuden er det nødvendigt til stadighed at foretage et kostbart opmudringsarbejde for at holde den ovenfor nævnte ringe dybde. Med lidt overdrivelse skriver Bruun, at »én nats frost lukker fjorden, og den ligger da almindeligvis tilfrosset til langt ud på foråret «. Men at den gennemsnitlige wislægningsperiode«, d. v. s. "dage med is er betydelig længere i Haderslev fjord end i Årøsund, hvor en stærk strøm op gennem bæltet er med til at formindske islægningen, kan ikke undre. I de 23 vintre fra 1929/30 til 1951/52 var der således 34,8 dage med is på Haderslev fjord, medens der $\mathrm{i}$ samme periode kun var 15,2 dage med is ved Årøsund.22 Denne omstændighed bevirkede ofte, at skibe på grund af tidlig islægning i Haderslev fjord måtte losse den til Haderslev bestemte ladning i Årøsund, hvorfra varerne så blev ført over land til Haderslev.

Ved selve Årøsund var der — »ved postgården « — bygget en havn for postfartøjerne, men denne havn kunne dog også benyttes af andre småskibe. Den havde en dybde af 9-10 fod, men var ikke let at besejle, idet indløbet kun var 18 alen bredt." Agent Bruun giver $\mathrm{i}$ sin indberetning den overraskende oplysning, at havnen $\mathrm{i}$ Ãrøsund - efter overslag af havnedirektør Litte og digeinspektør, kaptajn Christensen - skulle kunne omdannes til en almindelig koffardihavn med plads til 50 store skibe for den ubetydelige sum af $4000 \mathrm{rdl}$.

Kyststrækningen i nærheden af Årøsund frembød flere steder udmærkede ankerpladser for større skibe, især omkring mundingen af Haderslev fjord. De mest kendte ankerpladser var her den ydre red mellem Ørbyhage og Årø eller i bassinet ved Stevelt «, ${ }^{24}$ umiddelbart ved fjordmundingen. De største skibe, der lå på den ydre red, lossede og ladede ved hjxlp af lægtere, der forte ladningen ind til byen. Lxgterne kunne som regel tage 4 kommercelæster ( 8 tons). De skibe, der kun behøvede indtil 12 fod vand, kunne gå ind til Stevelt strand. Agent Bruun meddeler, at Haderslev årligt modtager alene af trælast - 30-40 svenske og finske skibsladninger, som udlosses i nærheden af Arøsund og derefter transporteres over land til Haderslev, og han tilføjer: "At udskibning ved Årøsund og transport pr. jernbane til Haderslev vil træde i stedet for den tidsspildende og besværlige sejlads langs Haderslev fjord og Arrøsund blive Haderslevs havn, er uden for al tvivl«. Og i skrivelsen af 8. oktober 1844 hedder det $\mathrm{i}$ bilaget om rentabilitet, at Årøsund „først for alvor vil 
få betydning, når en skinnevej gør det muligt for de forskellige byer at benytte sig af denne havn «. Og videre hedder det $\mathrm{i}$ denne skrivelse herom: "Det kan med sikkerhed ventes, at der på jernbanen fra Ảbenrå til Årøsund vil komme en meget stærk trafik, navnlig på den årstid, hvor dampskibene fra Kiel og Flensborg ikke kan gå til søsu.

Man er overbevist om, at en meget betydelig del af de varer, der fra syd sendes til Haderslev, vil blive viderebefordret over Årøsund, ligesom man forudser, at trafikken fra store dele af Jylland og det vestlige Slesvig næsten udelukkende vil passere denne strækning. Desuden mener komiteen, at en jernbane fra Arøsund uden tvivl vil blive den foretrukne vej for Fyns eks- og import via FlensborgHusum-Tønning banen eller til Hamborg.

Endelig kan det anfores, at agent Bruun i sin indberetning skriver, at Årøsund er et "almindeligt « bade- og forlystelsessted for indbyggerne i Haderslev, Christiansfeld og omegn. Han meddeler endog, at stedet "besøges årligt af mindst 4000 personer «, og anslår, at dette tal vil stige til 18.000 , når jernbanen kommer.

Arøsund var altså efter agent Bruuns og hele komiteens mening det sted, der var det helt rigtige som udgangspunkt for den projekterede jernbane. I det foregående har det særligt været de lokale forhold, der har været omtalt. Men ansøgningen af 8 . oktober $1844 \mathrm{og}$ det dermed følgende bilag om rentabiliteten behandler på en ret indgående måde også den betydning, som den ønskede jernbane efter komiteens opfattelse vil få for Slesvigs og Jyllands trafik.

Af begyndelsen af skrivelsen fremgår det, at komiteen er overbevist om, at denne jernbane vil kunne få stor betydning for et udstrakt område. "Betragter vi - på et kort over Danmark og hertugdømmerne - den linje, som den projekterede jernbane fra Haderslev til Ảbenrå kommer til at følge, så ser vi, at den er den eneste rigtige afløbslinje til lands for det nordlige Slesvig og hele Jylland«. Derefter prøver man på nærmere at begrunde dette ved for det første at påpege, hvorledes Haderslev-Ảbenrå banen, der ganske vist kommer til at ligge kun 2 mil fra Østersøen mod 6 mil fra Nordsøen, alligevel må siges at forløbe gennem midten af Slesvig, da den østlige del er af storre betydning og txttere befolket end den vestlige del. Og dernæst beskrives, hvorledes Jylland nord for Haderslev får en større udstrækning mod øst. "En linje, der fra denne by trækkes 
mod nord, vil omtrent ramme Viborg, således at alle vigtigere byer og langt den bedste del af landet kommer til at ligge øst for den. Det er indlysende, at dette vil udøve en stor indflydelse på trafikken på en kommende bane, ligesom der ikke synes at kunne være tvivl om, at et så fuldkommengjort befordringsmiddel som en skinnevej i det østlige Slesvig vil trække hele trafikken mellem det vestlige Jylland og de sydligere egne til sig", og dette vil endnu mere blive tilfældet, når chausseen fra Ribe til Haderslev - forhåbentlig snart - bliver til virkelighed. Dermed vil der være skabt en bekvem forbindelse til jernbanen.

Senere $\mathrm{i}$ skrivelsen går man nærmere ind på forbindelsen mod vest. Den ovenfor nævnte chaussé fra Haderslev til Ribe var optaget i det hovednet, som $i$ vejloven af 1842 var planlagt $i$ hertugdømmerne, og man håber, at den vil blive anlagt hurtigere, end det fremgår af rakkefølgen for vejarbejderne i loven, idet trafikken mellem Haderslev og Ribe stadig tiltager, og behovet for en hovedvej trænger sig mere og mere på. At en sådan hovedvej vil have en betydelig indflydelse »er for klart til, at det behøver at blive nærmere bevist $\ll$.

Men lige så vigtig, som hovedvejen til Ribe vil være for Haderslev, lige så vigtig vil jernbanen fra Flensborg over Husum til Tønning, som nu har fået koncession, blive. Haderslevs handel er ikke altid bundet til verdenshandelsbyen Hamborg, men den går også til England og Holland. Det ville være en stor velgerning for landet, hvis man kunne finde en lettelse for transporten her. "Det er ofte sket, at man - alene på grund af vanskeligheder, der har været med at få varerne befordret - har måttet henvende sig til og antage en mellemhandler i Hamborg. Den eneste nordsøhavn, som Haderslev og dens velsignede omegn - hidtil har kunnet benytte, er Ribe eller egentlig Sønderho på Fanø, men for det første er vejen til Ribe under al kritik dårlig, og for det andet er adgangen til det åbne hav forbundet med mange besværligheder og farer på grund af det lavvandede farvand i Ribe å og omkring Fanø. Haderslev har meget sjældent kunnet benytte denne vej til afsætning af varer og til import«.

Det var således store forventninger, som komiteen nærede til den jernbane, som den med så stor energi arbejdede for. Men det var ikke alle, der var af samme mening. Et meget tydeligt eksempel på dette er det bønskrift, som bønderne i Hajstrup den 30. juli 1844 sendte 
ti] kongen, og som er skrevet i en så særpræget stil, at skrivelsen fortjener at bringes $i$ sin fulde ordlyd og med den originale retskrivning og tegnsætning:

"Med undersaatlig Tillid og Beskedenhed nærmer allerunderdanigst underskrevne Jorddyrkere i Byen Haystrup sig Deres Kongelige Majestxts Thron for at nedlxgge i dyb Ydmyghed deres Hierters Følelser og Ønsker.

Trindt omkring os $\mathrm{i}$ heele Naturen oiner vi et altforbarmende faderlig sindede Vxsen imod alle sine Skabninger, hvilket ogsaa haver anbetroet Deres Kongelige Maytt. det danske Monarkiets Scepter for at udøve Ret og Retfærdighed imod det Allerhøistdem anbetroede Folk.

Overbeviist om disse Sandheder tror vi, at Deres Kongelige Maytt. omfatter alle Allerhøistderes Undersaatter med en sliig Landesfaderlig Kierlighed, efter hvilken den Enkeltes Fordeele maa vige for det almindelige Vel.

Det synes os, Allernaadigste Konge og Herre ! at vore Eiendomme, nedarvede af vore Forfædre, trues af en udvortes Fiende, der kunde forøge de Tyngder og Byrder, vore hensovede Forfædre saa taalmodigen og troligen have baaret, hvilke ogsaa vi allerunderdanigst Underskrevne have bestræbt os at udrede. I disse Dage, Allernaadigste Konge og Herre ! er foruden nogen forregaaende Advarsel Nivelleringen forretaget over den projecterede Jernbane fra Haderslev til Aarøsund, og det midt igiennem vore Kornmarker, vor Forhaabning og Trøst, midt igiennem vore Indhegninger, levende og døde, hvor vore Kreaturer fredeligen græsser, uden mindste Bekymring om de Huller og Aabninger saadanne Forretagender føre sxdvanligen med sig. Vi tror ikke, at det er Deres Kongelige Maytt. Villie, at det skulde skee imedens Kornet staaer endnu paa Marken. Ikke uden Bekymring og veemodige Følelser er den største Deel af denne Sommer henrunden for os under ugunstige Omstændigheder formedelst vedvarende Tørhed og Kulde. Den forrestaaende Høst kan derfor kun regnes iblandt de maadelige. Naar nu til disse nedslaaende Iagttagelser en ny Masse af Tyngder og Byrder og Indskrænkninger truer os: da kan vi saa letteligen paa den Tanke komme: hvormed skal vi i Fremtiden betale Udgivter til Staten, Amtet, Communen o. s. v. Naar der frarives os en Deel af det Land, hvorpaa vore Forfædre, hvorpaa vi have ernæret os, til Jernbanen; 
en anden Deel af vor Mark bliver taget fra os til Indhegningen for Jernbanen; vi taber en tredie Deel til nye Veianlæg bag Jernbanen; hvilken Godtgiørelse kan vi vel vente for alle disse Opofrelser ? ! Hvorledes bliver det med Udgivterne for de Stykker Jord vi haver ikke mere i Nytte og i Brug, af hvilke vi efter Rettens Norm og Rettesnor da heller ikke kan betale nogensomhelst Udgivter? Skal vi maaskee blive nødsaget til at kiøre $1 / 8$ eller $1 / 4$ Miil omkring for at komme til dette Stykke Land, der ligger en Steenkast fra vore Gaarde, vi ellers saa letteligen kunde komme til, men nu ikke, da Jernbanen haver giennemskaaren vor Mark $\mathrm{i}$ hvilkens lovlige Besiddelse vi befinde os, da der er lovet os i vore Contracter, at vi maa benytte og bruge den, som vi bedst viide og forstaae ?!

Det synes os, Allernaadigste Konge og Herre ! paa en saa liden Strxkning som fra Haderslev til Aarøsund en unyttig Bekostning, en Bekostning som indtil Verdens Ende ikke kan godtgiøre de Opofrelser og Ulemper, dette vil føre med sig for Landmanden!

Vi betale til Chausseerne, vi underholde desuden mange andre Landeveie og Biveie, skal nu foruden denne Mængde af Veie Jernbanen giennemskære dette ikke betydelige Land: saa synes det os alt for meget, og der bliver efter vor Talemaade Bidter og Brokker tilbage !!

Hvilken Nytte og Gavn kan vel hele Landet i Almindelighed have ved disse Jernbaner. Hvilken Nytte og Gavn kan Landmanden vel i Særdeleshed vente af disse? Vi tror slet ingen, men den ene Ulempe efter den anden. Slutteligen bemærker vi endnu i dybeste Underdanighed, at Haystrup Bys Marker ligger med omtrent $3 / 4$ norden for Byen, hvor Jernbanen er nivelleret, og er over $1 / 4$ Miil lang.

Efter at vi nu i Simpelhed og Korthed have oploftet vor ringe Røst til vor Allernaadigste Landsfader og Konge bønfalder vi Kongernes Konge, at han vil tage Deres Maytt. i sin almægtige Varetægt, og føie det saaledes, at det kongelige Hierte bliver ikke utilgængelig ved tro Undersaatters allerunderdanigste Forrestillinger.

I allerunderdanigste Forventning om allerfuld-naadigste Bønhørelse henlever vi Deres Kongelige Maytt.

\section{allerunderdanigst trolydige Undersaatter}

Erichsen, Friederich Schytt, B. Decker, Peter Enevoldsen, Friederich Hansen, Mads Jensen Krag, Niels Johannsen, Bertel Nissen, Peder Bertelsens Enke, Jørgen Jørgensen, Jørgen Clausens Enke, Nis Hansens Enke«. 
Men hvorledes stillede mulighederne sig nu for forrentningen af den projekterede jernbane? Også dette spørgsmål blev gjort til genstand for en meget grundig behandling, og resultatet af dette vanskelige arbejde blev nedfældet $i$ et bilag på 14 foliosider: "Rentabilität einer Apenrade-Hadersleben-Aarøsunder Eisenbahn «.

Komiteen erkender fuldt og helt, hvor vanskeligt det er at foretage en beregning af den projekterede jernbanes rentabilitet på grundlag af de bestånde forhold, men den mener dog, at beregningerne er af en sådan art, at de viser, at anlægget af en skinnevej er velmotiveret, selvom springet fra "sandveje« til jernbane dog vel nok er så stort, at der må tages hensyn til det ved beregningerne.

Hvad for det første persontrafikken angår, så gik man ud fra de tal, der for året 1843 forelå fra Haderslevs postkontor og fra politikontoret i Haderslev.

Efter oplysninger fra postkontoret blev der herfra i dette år til og fra Abenrå og til og fra Årøsund ialt befordret 5490 personer med de forskellige kategorier af postvogne, men derudover anslår komiteen, at 7000 havde befærdet disse strækninger i private vogne, således at det samlede antal rejsende pr. vogn blev 12.490 .

Opgørelsen over, hvor mange der i 1843 tilbagelagde de nævnte vejstrækninger til fods, hviler unægteligt på et meget spinkelt grundlag. Man gik ud fra det antal vandrebøger og de pas, der var blevet visiteret af politiet. Det var ialt 5700 , men man var samtidig klar over, at det langtfra var alle, der havde vandrebog eller pas, og man skønnede derfor, at antallet af dem, der rejste til fods, men som ikke havde vandrebog eller pas, var ca. 11.400 , d. v.s. det dobbelte af det antal, som politikontoret opgav. Det samlede antal rejsende til fods skulle altså $i 1843$ have været ca. 17.100.

Alt $\mathrm{i}$ alt skulle der således på strækningerne Haderslev-Ảbenrå og Haderslev-Årøsund have været ca. 29.590 rejsende i 1843, og komiteen mener, at man skønner lavt, når man regner med, at dette tal vil blive tredoblet, når jernbanen kommer. Man anslår altså det årlige passagerantal på den projekterede jernbane til at ville blive 88.800 og drister sig endog til at gå så vidt, at man angiver, at af dette antal passagerer vil 4440 køre på 1. klasse, 22.200 på 2. klasse og 62.160 på 3. klasse.

Med hensyn til godstransporten anførte man udfra Statistisk Tabelværk og "andre tilforladelige kilder «, at den mængde land- 
brugsprodukter, der årligt førtes gennem Haderslev, beløb sig til 40.000 centner fra Jylland, 12.000 centner fra Fyn og 9000 centner fra Haderslev og omegn. Disse landbrugsprodukter omfattede smør, huder, skind, talg, voks, fåreuld, uldvarer, saltet flæsk og kød i tønder samt "grønt flæsk til skibsproviantering og til eksport fra Flensborg og Åbenrå «.

Hertil kom så udførslen af industriprodukter m. v. fra Haderslev og omegn, hvilket ialt beløb sig til 30.000 centner. Heraf udgjorde støbejernsvarer fra jernstøberiet i Haderslev samt træ til skibsværfterne i Ảbenrå 4000 centner, medens de øvrige 26.000 centner omfattede forskellige slags gryn fra dampmøllen i Haderslev og fra andre møller, samt oliekager fra oliemøllen i Christiansdal og uldvarer, lys, honning og tobaksvarer fra Christiansfeld.

Efter oplysninger fra "den første kvæghandler i Jylland ", major von Ingwersen, omfattede kvægudførslen fra Jylland til Sydslesvig og Holsten 26.500 okser. Heraf anslog man, at der med jernbanen ville blive transporteret 9000 magre okser samt yderligere 2000 fede okser, 2000 kvier og 2000 magre køer. Med hensyn til ungkreaturer, svin og får manglede man nøjagtige oplysninger, men komiteen anslog - hvad man regnede med var sxrdeles lavt - eksporten af disse dyr til at ville udgøre 20.000 centner. Endelig omfattede udførslen 2000 heste samt 17.000 centner korn plus frø.

Hvad angår indførslen, så opgives efter oplysninger fra toldkammeret i Haderslev, at der fra Flensborg ad søvejen er blevet indført 27.000 centner diverse varer, medens der ad landevejen er kommet 6750 centner postsager. Af kolonial- og manufakturvarer blev der indført ca. 11.000 centner, især fra Hamborg og det øvrige Tyskland. Fra Holsten blev der indført ca. 5000 centner forskellige fabriksvarer, såsom tøj, cikorie, sukker og sirup.

Angående størrelsen af den mængde tørv, der blev indført fra moserne ved Vartenberg, og som dxkkede langt den største del af Haderslevs forbrug, er der nogen uoverensstemmelse mellem skrivelsen om "Rentabilität «, hvor det angives, at indførslen er 12.000 lies à 25 centner, og opgivelserne $i$ en skrivelse af 4 . november 1844 , hvor det opgives, at indførslen af torv "har vi regnet til 8000 læes à 25 centner * - et tal, som man mener er sat lavt, når man bemærker, at Haderslev har 600 huse, der hvert regnes at bruge 7 læs tørv årligt, og 1 dampmølle, 2 dampbrænderier, 2 kalk- og teglbrænderier 
samt 20 mindre brænderier og 16 bagere, som alle bruger tørv. Desuden regnede man med, at der fra moserne ved Vartenberg årligt ville blive transporteret ca. 50.000 centner pr. jernbane til Åbenrå. Endelig er det opgivet, at transitvarerne fra udlandet til Jylland og de danske øer vil udgøre 75.000 centner, således at den samlede varetransport på strækningen mellem Haderslev og Ảbenrå skulle blive 507.750 centner eller ca. 25.000 tons årligt.

Selvom det skøn, som man foretog over, hvor stor godstransporten mellem Haderslev og Ảbenrå ville blive, når jernbanen kom, var behæftet med meget stor usikkerhed, så hvilede det dog på tallene fra den godsomsxtning, der allerede på dette tidspunkt fandt sted på denne strækning. Helt anderledes stillede det sig med hensyn til strækningen fra Haderslev til Årøsund, hvor der først ville opstå en godstransport, når jernbanen kom. Hvor stor godstrafikken her ville blive, kunne naturligvis ikke angives med blot nogenlunde sikkerhed, men efter komiteens opfattelse kunne det på ingen måde være for højt ansat, når man anslog, at den samlede godsomsætning mellem Haderslev og Ảrøsund ville blive ca. 400.000 centner. Man regnede det for udenfor al tvivl, at Årøsund-banen ville blive benyttet af Fyns eks- og import til videre transport enten med banen FlensborgHusum-Tønning eller til Hamborg.

Afsnittet om den projekterede jernbanes rentabilitet slutter med en rekapitulation, hvori er udregnet de forventede indtægter ved person-, gods- og kreaturtransporten samt udgifterne ved driften af den $5^{1 / 2}$ mil lange jernbane. Efter denne beregning ville personbefordringen ialt kunne indbringe 119.880 mark, der fordelte sig for passagererne på 1., 2. og 3. klasse med henholdsvis $13.320,44.400$ og 62.160 mark. Indtægterne ved gods- og kreaturtransporterne ville efter beregningen beløbe sig til 113.585 mark, således at jernbanernes samlede indtxgter ville blive ca. 233.500 mark. Driftsudgifter ansloges til 110.000 mark, således at der ville blive et driftsoverskud på ca. 123.500 mark.

Men trods det meget store og grundige arbejde, som Haderslevkomiteen havde nedlagt $i$ ansøgningen af 8 . oktober 1844, var den modtagelse, som den fik i Den kongelige Jernbanekommission, mildest talt kølig. Man kunne slet ikke dele komiteens lyse syn på den projekterede jernbanes forventede rentabilitet, men mente tværtimod, at denne aldeles ikke var bevist ved de beregninger, der var foretaget. 
Den kongelige Jernbanekommissions svar afsendtes allerede den 31. oktober, og med dette svar returneredes de skrivelser, der havde været bilagt ansøgningen af 8. oktober. Men det er bemærkelsesværdigt, at kommissionen i sit svar på komiteens ansøgning om koncession overhovedet ikke nævner ordet "koncession ".

Det hedder i svaret meget klart: "Som svar på behagelig ansøgning af 8. d. m. fra den til bygning af en jernbane fra Åbenrå over Haderslev til Årøsund konstituerede komité skal kommissionen herved meddele denne, at muligheden for udbytte af den projekterede jcrnbane ikke er så tydeligt påvist ... «, at kommissionen på grundlag af de modtagne beregninger ser sig $\mathrm{i}$ stand til at indstille til kongen, at komiteen får tilladelsen til at foretage en tegning af de for banens anlæg nødvendige aktier.

Det er således et meget bestemt afslag, hvoraf det tydeligt fremgår, at man ikke engang finder anledning til at anmode komiteen om at indsende det program for aktietegning, som altid bor gå forud for en tildeling af koncession.

Men trods dette gav Haderslev-komiteen alligevel ikke op. Tiden var knap, for det var jo blevet meddelt dem, der havde tegnet aktier, at de ikke var bundet af deres tegning, hvis komiteen ikke havde fået den ønskede koncession senest den 1. december 1844.

Allerede den 4. november afsendte agenterne J. C. Petersen og C. H. Bruun som befuldmægtigede for Haderslev-komiteen endnu en ansøgning - denne gang på dansk - "om koncession til bemeldte jernbanes anlæg og eneret til sammes benyttelse", og dette andragende fulgtes allerede den 6. november op af en ny skrivelse fra Haderslev-komiteen.

Den kongelige Jernbanekommissions medlemmer behandlede sagen meget grundigt, men af den indstilling, som de den 7 , november foretog til kommissionsbetænkning, fremgår det med stor tydelighed, at man ikke kunne anbefale, at komiteen i Haderslev fik den onskede koncession.

I indstillingen påpeges, hvorledes komiteen for anlægget af en jernbane fra Åbenrå over Haderslev til Årøsund befinder sig i samme situation som de andre komiteer $\mathrm{i}$ hertugdømmet Slesvig, nemlig komiteerne for en jernbane fra Rendsborg over Slesvig til Flensborg og for en jernbane fra Flensborg til Ảbenrå. Disse komiteer har været af den opfattelse, at de, når de havde fået tilladelsen til at 
foretage nivelleringer, ikke var forpligtede til yderligere at ansøge om tilladelse til at lade foretage tegning af aktier.

Kommissionen har allerede ved skrivelse af 31. august 1844 meddelt Haderslev-komiteen, at den - i overensstemmelse med bestemmelserne $i$ bekendtgørelserne af 18 . maj 1840 og 19. juni $1844-$ med indsendelsen af resultatet af den foretagne nivellering og overslaget over rentabiliteten skulle andrage om tilladelse til at lade udskrive tegning af aktier, og at de allerede stedfundne aktietegninger for så vidt savnede et grundlag, som der forst efter en nærmere undersøgelse af foretagendet kunne træffes afgørelse om, hvorvidt tilladelsen kunne gives.

Efter Haderslev-komiteens opfattelse kunue bekendtgørelsen af 19. juni 1844 ikke komme $\mathrm{i}$ anvendelse $\mathrm{i}$ det foreliggende tilf $x$ lde, idet tegningen af aktier var afsluttet på et tidligere tidspunkt. I ansegningen af 8. oktober skriver komiteen blandt andet: "Thi da det i nævnte bekendtgørelse af 19 . juni d. å. ikke er foreskrevet, at den skulle have tilbagevirkende kraft, så har på den tid, da aktietegningerne til den projekterede jernbane blev foretaget, under hensyntagen til, at jernbaneforordningen af 18 . maj 1840 intetsteds nævner nødvendigheden af en tilladelse til aktietegninger, en forpligtelse til at indhente en sådan tilladelse ikke været til stede, hvorfor vore aktietegninger ikke hører til dem, der savner ethvert grundlag «.

Kommissionen er imidlertid af en anden mening og hævder, at det ville være i modstrid med bestemmelserne, hvis Ảbenrå-HaderslevÅrøsund-komiteen, som endnu ikke havde ansøgt om denne tilladelse til aktietegning, nu fik koncession til banen, og at de to andre komiteer, der er i fuldstændig samme situation, med rette ville kunne føle sig uretfærdigt behandlet.

Af denne grund kan koncessionen ikke tildeles. De befuldmægtigede har $\mathrm{i}$ deres fornyede ansøgning af 4 . november - skriver kommissionen - ene og alene ansøgt om at få koncession, men kommissionen må henholde sig til skrivelsen af 31 . oktober og bemærker, at den omstændighed, at aktietegnerne ikke er forpligtede af deres tegning, hvis komiteen ikke får koncessionen inden 1. december 1844, ikke kan foranledige kommissionen til at $x$ ndre sin beslutning.

Kommissionen fastslår yderligere, at det udelukkende er komiteens egen skyld, at sagen er blevet så forsinket, og skriver direkte, at 
i betragtning af, at tilladelsen til nivellering forelå allerede den 15. juni, burde ansøgning om at måtte lade foretage tegning af aktier have været indsendt på et meget tidligere tidspunkt.

Derefter går kommissionsmedlemmernes indstilling over til at behandle resultatet af den foretagne nivellering og af beregningerne over den projekterede jernbanes rentabilitet. Der er for det forste en betragtning af stigningsforholdene i det terræn, som banelinjen skulle føres igennem. Haderslev-komiteen har som sin opfattelse fremhævet, at disse stigningsforhold i det store og hele er tilfredsstillende. Denne opfattelse deles ikke af kommissionen, især ikke når den sammenligner med forholdene ved andre jernbaneanlxg. Tværtimod forekommer det kommissionen, at dette, at $1 / \mathrm{s}$ af banestrakningen har en stigning på 1:100, er så betydeligt, at man mener, at de anlægsudgifter, som komiteen anslår, ikke kan være tilstrækkelige.

Også med hensyn til den opstillede rentabilitet stiller kommissionen sig meget tvivlende. Komiteen regner med, at jernbanen vil fă et årligt passagerantal på ca. 88.800, men efter kommissionens opfattelse synes dette tal at være meget vilkårligt ansat, og det samme gxlder størrelsen af den anslåede godsbefordring. Kommissionen betegner beregningen af godsbefordringen på strækningen mellem Ảbenrå og Haderslev som "meget vovet og usandsynlig", og hvad angår godsbefordringen på strxkningen mellem Haderslev og Arøsund, finder man, at den foretagne opgørelse må betegnes som "meget tvivlsom «, da der for tiden - som komiteen også anfører overhovedet ikke er nogen godstrafik på denne strækning.

I det hele taget er det kommissionens opfattelse, at den opstillede rentabilitet synes at vxre altfor utilstrxkkelig til at kunne skabe grundlag for en ansegning om tilladelse til aktietegning.

Men hertil kommer endnu en omstændighed, der må tages i betragtning ved behandling af den foreliggende ansøgning, og det er, at der fra Middelfart og Odense kommuner nu er indkommet protester mod, at jernbanen skulle komme til at gå over Assens og Ärøsund.

Kommissionen konkluderer altså faktisk i, at den ikke finder, at der er anledning til at anmode Haderslev-komiteen om at indsende det program til aktietegning, som bør gå forud for meddelelse af "den allerede nu ansøgte koncession " - så meget mere, som en jernbane fra Ãrøsund til Åbenrå ikke vil få nogen betydning, når for- 
længelsen over Flensborg til Rendsborg ikke kommer $\mathrm{i}$ stand, og hertil kommer, at det endnu ikke er afgjort, om den fynske bane skal gå fra Odense over Assens eller over Middelfart til Snoghøj og derfra videre over Kolding til hertugdømmet Slesvig.

Allerede den 9. november foreligger den kongelige resolution, der pålægger jernbanekommissionen overfor Haderslev-komiteens befuldmxgtigede, agenterne J. C. Petersen og C. H. Bruun »... ved en motiveret beslutning at tilkendegive, at denne deres anmodning ikke kan imødekommes«. Den 12. november meddelte kommissionen så Haderslev-komiteen afslaget $i$ en skrivelse, der bringer hovedpunkterne af det, der er udtalt $\mathrm{i}$ kommissionsmedlemmernes indstilling.

Efter dette kategoriske afslag lå jernbanesagen så stille det meste af et år, men det betød ikke, at man i Haderslev havde opgivet tanken om at få en jernbane til Årøsund.

Det følgende år blev sagen taget op på ny af "Den slesvig-holstenske patriotiske Forening i Haderslev «, der var blevet stiftet $\mathrm{i}$ juli 1845. Den 6. oktober afholdtes der generalforsamling i denne forening, og her blev det enstemmigt besluttet at sende et andragende til kongen om, at der nu, da jernbanen mellem Neumünster og Rendsborg var blevet åbnet - det skete den 18. september $1845-$ byggedes en forlængelse af denne jernbane til Flensborg og derfra videre over Åbenrå og Haderslev til Ãrøsund. Det, der først og fremmest var magtpåliggende for ansøgerne, var naturligvis at få den »direkte og umiddelbare forbindelse med Hamborgs verdensmarked «. I ansøgningen blev det forøvrigt fremhxvet, at "navnlig havde banelinjen fra Åbenrå over Haderslev til Årøsund en mageløs eklatant aktietegning at fremlægge

Andragendet, der blev indsendt den 30 . oktober 1845, omtaler forst, hvorledes ansøgningen af 8 . oktober 1844 imod al forventning blev afslået. "Vi undlader ærbødigst enhver bemærkning om denne for os så ugunstige allerhøjeste resolution «, hedder det $\mathrm{i}$ andragendet, »dog kan vi ikke undlade underdanigst at nedlægge vor beklagelse derover for tronen. $\mathrm{Nu}$ synes os tidspunktet gunstigt til allerunderdanigst hos Deres Majestxt at andrage på, at det ville behage højstsammes visdom, allernådigst at koncessionere jernbaneforbindelsen mellem Rendsborg og Flensborg, og hvis konjunkturerne atter skulle blive gunstige, at tilstede denne banestræknings forlængelse over Ábenrå og Haderslev til Årøsund “. ${ }^{25}$ 
Det var således helt rigtigt, når det $i$ en beretning $i$ "Lyna « for 21. januar 1846 om $»$ Den i Haderslev oprettede slesvig-holstenske patriotiske Forening « blandt andet hedder: "Først foretog foreningen igen den længe slumrende jernbanesag og indgav en ligeså kraftig, som $i$ et værdigt sprog skrevet og velmotiveret petition betræffende jernbanens forlængelse fra Rendsborg til Flensborg, umiddelbart til Hans Majestæet kongen «.

Heller ikke denne gang lykkedes det at få den onskede jernbane, men alligevel skete det $\mathrm{i}$ de følgende år flere gange, at man fra forskellig side var interesseret $i$ at bringe liv $i$ den gamle hovedforbindelse mellem Slesvig og de danske øer. Allerede i $1850 \mathrm{kom}$ den igen på tale, idet der $\mathrm{i}$ dette år for første gang fremkom en samlet jernbaneplan for "Danmark og Slesvig « — en plan, der kom til at spille en meget betydelig rolle $\mathrm{i}$ jernbanediskussionen og jernbanepolitikken. Denne plan, der blev offentliggjort i 1850 i et lille skrift med titlen "Motiveret Forslag til en successiv Fuldførelse af et Jernbane-, Dampskibs- og Telegraphsystem for Danmark og Slesvig«, var fremsat af kontorchef ved postvæsenet Frederik Klee og folketingsmand, dr. C. M. Poulsen. Planen var i udprxget grad baseret på tværbaner. Hovedbanen skulle fra København gå over Korsør og Middelfart til Hjerting ved Ho-bugten. Fra Korsør skulle der så etableres dampskibsforbindelse til Århus, hvorfra der skulle fores en jernbane til Skive, samt til Flensborg, hvorfra der skulle være en jernbane til Husum og Tønning.

Et af hovedsynspunkterne for forslagsstillerne var "at styrke foreningen mellem Danmark og Slesvig så meget som muligt; at lade Slesvig tilflyde så mange åndelige og materielle goder som muligt; at bringe det til at føle og erkende, at det $\mathrm{i}$ en forbindelse med Danmark lever mere trygt, frit og lykkeligt, end det hidtil har levet $i$ den slesvig-holstenske".

Derfor skulle Slesvig gennem dette trafiksystem knyttes fast til det øvrige Danmark. Man foreslog, at der på Fyn skulle anlægges en bibane, der fra et sted vest for Odense skulle gå til Assens. I forbindelse med denne bane skulle der så i Slesvig anlægges en bibane, som over Haderslev skulle gå til Skrydstrup eller Over Jerstal alt efter, hvor den jyske længdebane kom til at gå.

Den 18. december 1862 blev spørgsmålet om at benytte den gamle fxrgeforbindelse fra Assens til Arøsund nævnt i folketinget, hvor 


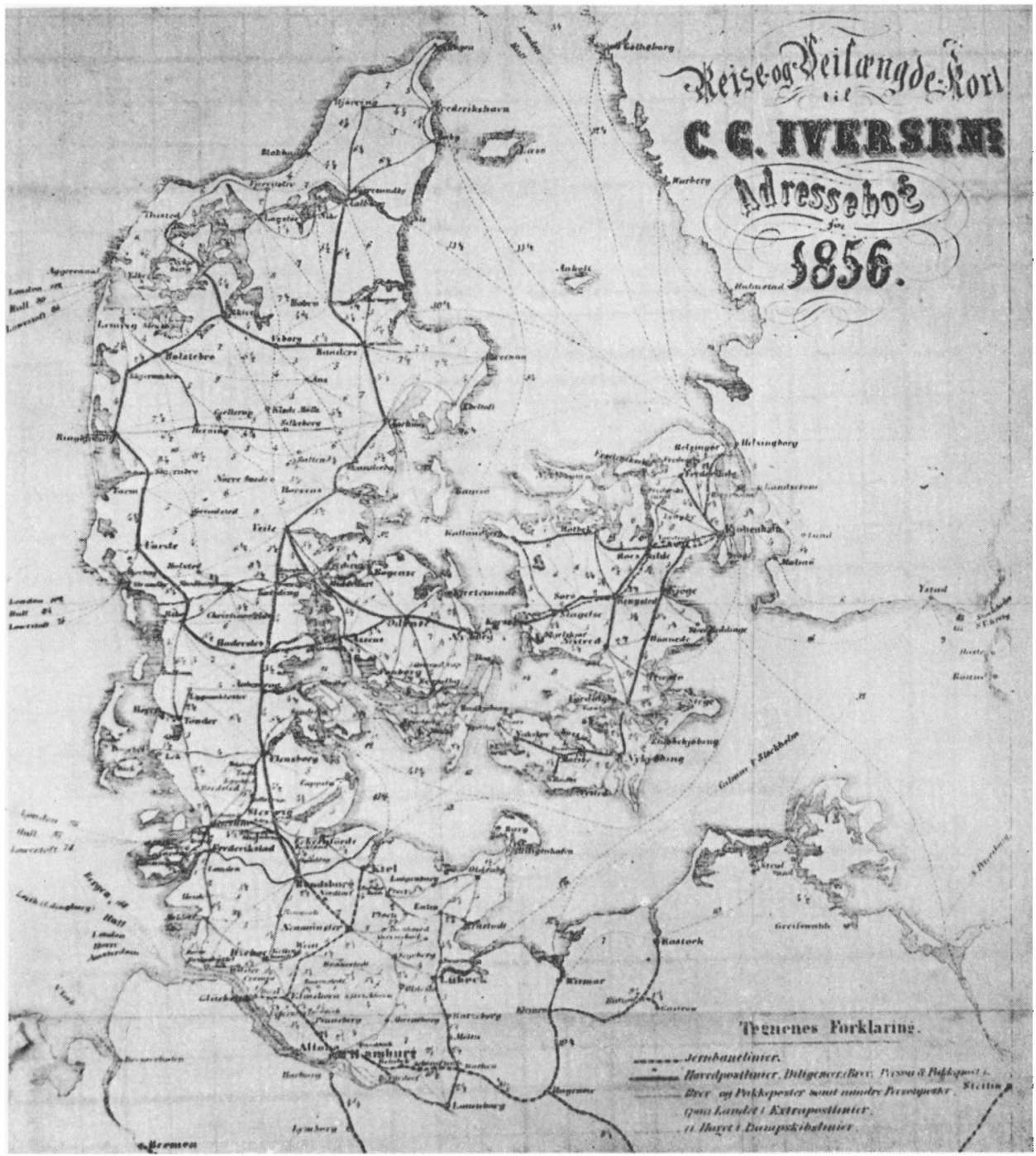

Hovedpostruterne 1856.

den senere teaterchef, kaptajn Fallesen omtalte den $\mathrm{i}$ forbindelse med forslaget om at anlægge en jernbane fra Skalbjerg - på hovedlinjen mellem Odense og Middelfart - til Assens. Det skete dog uden nogen kraft og overbevisning. I følge folketingsreferatet sagde Falle- 
sen rent ud, at "det naturligvis ikke er min mening, at der skal rejses nogen diskussion om denne sag. Jeg har kun villet udtale et ønske, som meget er lagt mig på sinde fra den kreds, jeg har den ære at repræsentere«. Der blev derfor naturligvis heller ikke gjort noget ved dette spørgsmål.

Men også $i$ den tyske tid kom der planer frem om at få en jernbane til Årøsund. Man beskæftigede sig i årene omkring 1889 meget med tanken om at bygge en havn på vestkysten af Sønderjylland. Der var først og fremmest tale om en havn ved Havneby på Rømø, men desuden var der forslag fremme om at anlægge en havn ved Emmerlev nord for Højer eller endog på Jordsand, og i forbindelse med en sådan havn skulle der anlægges en tvæerbane, der over Skærbæk, Toftlund og Vojens skulle føres til Haderslev og "statshavnen " Årøsund.

I en betænkning, som komiteen for en jernbane fra Haderslev over Toftlund og Skærbæk til Rømø udsendte i 1889, fremhæves de gode betingelser, som en havn ved Arøsund har, og der antydes endog muligheden for, at man ved en havneudvidelse her kan inddrage øen Årø i havneanlægget.

Ved bygningen af den nævnte jernbane vil - hedder det $\mathrm{i}$ komiteens skrivelse - Ārøsund havn i særlig grad om vinteren blive af samme betydning for den tyske handel som den påtxnkte havn på Rømø.

Jernbanen ville ikke alene betyde, at indbyggerne $\mathrm{i}$ den vestlige del af Haderslev kreds, der også omfattede Hviding herred og således gik fra kyst til kyst, ikke behøvede at tage den lange omvej over Tønder for at komme til kredsens hovedby, men jernbanen ville også bevirke, at landbrugsprodukterne lettere kunne bringes ud til en havn, og i særlig grad til en havn, hvorover der også kunne indføres varer som kul, træx, foderstoffer m. v.

Komiteens skrivelse slutter med følgende betragtninger: "Yderligere ville byen Haderslev med endnu større succes kunne opfylde sit med hengivenhed røgtede kald at vare højborg og midtpunkt for den endnu svage tyskhed i fædrelandets nordlige del. Men banen ville ikke blot blive til stor nytte for dette forholdsvis lille område. Den derved skabte korteste og samtidig ufarlige forbindelse mellem Nordsøen og Østersøen - hvis endepunkter er de to bedst tænkelige og næsten isfrie havne - ville uden tvivl blive til gavn for hele 
provinsen, og den ville åbne en med glæde hilst og benyttet ny forbindelse mellem Østersø- og Nordsøområderne. Den ville således $y$ tre sig ved velsignelsesrige virkninger $i$ hele det tyske norden og ville utvivlsomt også være ledsaget af velgørende følger for hele monarkiet . $^{2 *}$

Dette projekt kom dog ikke længere end på papiret. Få år efter fik Haderslev ganske vist sin jernbane til Årøsund, men det var rigtignok ikke det, man havde tænkt sig i 1844. For den smalsporede jernbane, som fra 1903 til 1938 gik fra Haderslev til Årøsund, havde - med de forskellige sving, den lavede - en længde på $27 \mathrm{~km}$, medens den direkte forbindelse ad landevejen kun er $15 \mathrm{~km}$.

I tiden lige efter genforeningen var spørgsmålet om det sønderjyske jernbanenets fremtidige udvikling naturligvis noget, der optog sindene meget. Også i disse år rejste der sig røster om at få en normalsporet jernbane til Årøsund og en færgeforbindelse herfra til Assens. Allerede den 23. juli 1919 blev der fra handels-, håndværkerog landboforeningerne $\mathrm{i}$ såvel Haderslev og omegn som Assens og omegn indgivet et andragende om statsfærge og normalsporet jernbaneforbindelse via Årøsund. ${ }^{27}$ Men nu var der kommet en ny faktor ind, nemlig planerne om en bro over Lille Bxlt, og en sådan bro måtte naturligvis bevirke, at tanken om en udbygning af trafikken over det gamle overfartssted nu blev skrinlagt.

\section{NOTER}

1. C. Beseke: Der Nord-Ostsee-Kanal. Kiel 1893.

2. De danske Statsbaner 1847-1947. København 1947, side 21.

3. O. Hedrich: Die Entwicklung des Schleswig-holsteinischen Eisenbahnwesens. Kiel 1915, side 64.

4. R. Berg: De danske Jernbaner 1840-48. (Nationaløkonomisk Tidsskrift 3. R. V. 1897, side 235).

5. C. F. I. Dalgas: Vejle Amt, beskrevet efter Opfordring af Landhusholdningsselskabet. København 1826, side 136.

6. D. S. B. 1847-1947, side 24 .

7. Berlingske Tidende, 30. maj 1844 .

8. D. S. B. $1847-1947$, side 28.

9. D. S. B. 1847-1947, side 22 .

10. Sønderjyllands Historie IV, side 317.

11. Dannevirke, 13. april 1844.

12. Sønderjyllands Historie IV, side 317.

13. Berlingske Tidende, 3. juni 1844 .

14. Lyna, 5. november 1845. 
15. Den følgende redegorelse er, hvor ikke andet er anført, baseret på de aktstykker, der findes i pakken: Jernbanekommissionen: Afleveringer fra Statsarkivet i Kiel: Åbenrå-Haderslev-Ãrøsund banen 1844. (Rigsarkivet).

16. Berlingske Tidende, 27. maj 1844.

17. Haderslev amtsarkiv: Slesvig-holstenske regeringssager. Østeramt. 1843-44. (Landsarkivet i Ảbenrå).

18. Aug. Sach: Der Ursprung der Stadt Hadersleben. Haderslev 1892, side 63.

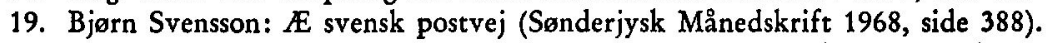

20. A. H. Behrendt: Haderslev Postkontor 1649-1949. Haderslev 1949, side 8.

21. Lauritz Maaløe: Assens gennem 700 Aar. Odense 1936, side 99.

22. N. H. Jacobsen: Lidt om Haderslev Fjord som søfartsvej (Geografisk Tidsskrift 52. bd., 1952-53), side $132 \mathrm{f}$.

23. Den danske Lods. 1. udg. 1843, side 224.

24. Interims-Reglement og Taxt (af 26. september 1846) for Lodsen ved Ørbyhage.

25. Lyna, 5. november 1845.

26. Pakken: Bygning af en jernbane Rømø-Toftlund-Vojens. 1889. (Landsarkivet i Ảbenrå).

Paul Langhans: Die Seehafen-Projekte an der schleswigschen Westküste (Petermanns Mitteilungen, bd. 36, 1890), side 122.

27. Betænkning afgiven af Den sønderjydske Jernbanekommission 1923. 